\title{
Do prémio e da crítica
}

\section{Rui Pina Coelho}

Carlos Porto, co-fundador e Presidente honorário da Associação Portuguesa de Críticos de Teatro até à data da sua morte em 2009, escrevia na introdução ao segundo volume do seu exemplar Em busca do teatro perdido (1973) que o "crítico não é um fantasma". Nesse mesmo texto considerava "infinitamente ridículo e extremamente cretino" o crítico que se isola do mundo e que se recusa partilhar "como qualquer outro cidadão-espectador a problemática do espectáculo teatral" (Porto 1973: 11). Eram declarações assertivas, património de uma crítica empenhada, de dimensão humanista, e de uma maneira comprometida de ver o mundo como um processo em construção. Eram declarações que denunciavam uma crença inabalável na relevância da crítica de teatro.

Hoje, querendo herdar a lição de Carlos Porto e o seu "espectadorismo activo" (Ibidem: 12), pugnamos por não ser nem fantasmas, nem ridículos, nem - já agora cretinos. Porém, as circunstâncias actuais para a crítica de teatro mudaram de forma radical. Os suportes tradicionais para a sua publicação e divulgação mudaram, o seu papel e articulação com as estruturas teatrais mudou, os modos de fazer são hoje outros e as condições para o seu exercício mudaram tremendamente. Acrescentando drama a estas mutações, um manifesto desinteresse pela crítica de teatro acompanhou toda esta mudança. Assim, navegando entre a estética, a história, a filosofia, a literatura e o jornalismo, a crítica não tem conseguido fugir àquilo que tem vindo a ser uma lenta e sufocante agonia.

Resistindo a este desencanto geral e apanhada na encruzilhada de uma caleidoscópica realidade teatral em permanente mutação, a crítica hoje enfrenta novos desafios e responde a novas necessidades. 0 crítico brasileiro Sérgio Salvia Coelho cria a estupenda imagem de um alfandegário num mundo sem fronteiras ou a de um "comentarista de futebol em um jogo de rugby" (Salvia Coelho 2009: 187188). Salvia Coelho alerta também para a perigosa confusão da crítica com jornalismo cultural que "pressionado pela decadência do mercado da mídia impressa tem pouca energia para ir contra a maré do marketing. Primeiro, vem a publicidade paga, depois, a divulgação do que está vendendo bem e, por fim, se sobrar espaço, o pensamento crítico" (Ibidem: 196), para concluir que "humilhado pelos editores, que the negam espaço e pelos criticados, que the cobram o espaço negado, o crítico de teatro, este pobre alfandegário sem fronteiras, estará sempre pronto a se maravilhar" (Ibidem: 197).

Preservar a inocência do espanto a que este crítico alude é tarefa árdua. Porque, entretanto, a crítica de teatro mudou-se para um bairro quase invisivel, quase desnecessário, quase inexistente. Pessoalmente, julgo que a crítica de teatro, quando serve, serve para prolongar a vida de um espectáculo. Serve para o inscrever na coisa pública - para provocar a memória e espevitar a discussão. Serve para expandir a zona de impacto de um espectáculo. Não serve para ajudar a escolher.

É por isso que considero estes Prémios da Crítica de grande importância. Não são - é certo - objecto de transmissão televisiva nem são momento de grande gala; não trazem nenhuma fortuna pessoal aos premiados nem aos mencionados, e menos ainda aos membros do júri. Correspondem apenas aos belos objectos que entregamos na cerimónia pública que este ano, uma vez mais, pudemos realizar no esplêndido Jardim de Inverno do São Luiz Teatro Municipal (por especial cortesia do seu Director, o Professor Jorge Salavisa) e aos textos justificativos que os acompanham, e que publicamos na Sinais de cena - uma revista inventada (e mantida esforçadamente), imaginese, por críticos de teatro.

Mas, por representarem um momento em que se voltam a discutir e a analisar espectáculos, encenações, percursos, interpretações, cenários e figurinos, enfim, por representarem um momento em que se volta a discutir teatro, estes Prémios da Crítica representam uma firme vontade da APCT em dar eco ao trabalho - cada vez mais difícil e feito em condições cada vez mais precárias, bem o sabemos - daqueles que se vão distinguindo, dos que vão perseverando ou dos que vão dando sólidos indícios de excelência e qualidade. Ano após ano. E para o ano há mais.

\section{Referências bibliográficas}

PORTO, Carlos (1973), Em busca do teatro perdido, vol. 2. Colecção Movimento, Lisboa, Plátano Editora.

SALVIA COELHO, Sérgio (2009), "O critico pós-dramático: Um alfandegário sem fronteiras" in 0 pós-dramático, orgs. Silvia Fernandes e J. Guinsburg, São Paulo, Perspectiva. 